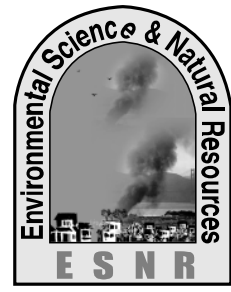

J. Environ. Sci. \& Natural Resources, 5(2): 23 - 28, 2012

ISSN 1999-7361

\title{
A Study on Watermelon (Citrullus Lanatus) Juice Preserved with Chemical Preservatives at Refrigeration Temperature
}

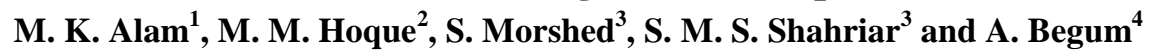 \\ ${ }^{1}$ Dept. of Food Processing and Engineering, ${ }^{3}$ Dept. of Applied Chemistry and Chemical Technology, \\ ${ }^{4}$ Dept. of Applied Food Science and Nutrition; \\ Chittagong Veterinary and Animal Sciences University, Khulsi, Chittagong \\ ${ }^{2}$ Dept. of Food Engineering and Tea Technology, Shahjalal University of Science and Technology, Sylhet
}

\section{Abstract}

This study was done to analyse the effect of chemical preservatives on watermelon juice. The samples were; pasteurized watermelon juice $\left(\mathrm{T}_{1}\right)$, pasteurized watermelon juice $+20 \%$ sucrose $\left(\mathrm{T}_{2}\right)$, pasteurized watermelon juice $+0.1 \%$ sodium benzoate $\left(\mathrm{T}_{3}\right)$, pasteurized watermelon juice $+20 \%$ sucrose $+0.1 \%$ sodium benzoate $\left(\mathrm{T}_{4}\right)$, pasteurized watermelon juice $+0.1 \%$ potassium sorbate $\left(\mathrm{T}_{5}\right)$, pasteurized watermelon juice $+20 \%$ sucrose $+0.1 \%$ potassium sorbate $\left(\mathrm{T}_{6}\right)$, pasteurized watermelon juice $+0.05 \%$ sodium benzoate $+0.05 \%$ potassium sorbate $\left(\mathrm{T}_{7}\right)$, pasteurized watermelon juice $+20 \%$ sucrose $+0.05 \%$ sodium benzoate $+0.05 \%$ potassium sorbate $\left(\mathrm{T}_{8}\right)$, pasteurized watermelon juice $+0.1 \%$ sodium benzoate $+0.1 \%$ potassium sorbate $\left(\mathrm{T}_{9}\right)$, pasteurized watermelon juice $+20 \%$ sucrose $+0.1 \%$ sodium benzoate $+0.1 \%$ potassium sorbate $\left(\mathrm{T}_{10}\right)$. The samples were stored at $4-15^{\circ} \mathrm{C}$ for three months. $\mathrm{T}_{1}$ and $\mathrm{T}_{2}$ were rejected soon due to spoilage. Minimum ascorbic acid content was reduced in $\mathrm{T}_{10}(23.85 \%)$, while maximum in $\mathrm{T}_{4}(44.44 \%)$. Minimum acidity was increased in $\mathrm{T}_{10}(50.00 \%)$, while maximum in $\mathrm{T}_{1}(107.69 \%)$. Treatments $\mathrm{T}_{10}, \mathrm{~T}_{9} \mathrm{~T}_{8}$ and $\mathrm{T}_{6}$ were found most acceptable in maintaining the sensory characteristics compared to others during storage. Among all the treated juice sample $\mathrm{T}_{10}$ was most effective in maintaining the sensory and nutritional quality during storage.

Key words: Watermelon juice, Pasteurization, Sucrose, Sodium Benzoate, Potassium Sorbate

\section{Introduction}

Watermelon is a warm-season crop and is grown worldwide, usually in the regions that have a long warm growing season (Snowdon, 1990). The plants have weak stems and climb by tendrils, which hang from tree as tall as 20 to 60 feet, the watermelon fruit matures on the ground. The drying of the tendril at the point of attachment the fruit stem to the vine is also considered a sign of maturity (Soteriadou, 1969). Because of consumer demand for sweet, flavorful watermelons, total sugar content is an important quality factor. One way to determine field maturity before harvest is to cut a few melons taken from random parts of the field and test their sugar level using a hand refractometer. High quality watermelon should have a sugar content (measured as soluble solid) of 10 percent or more in the flesh near the center of the melon (William, 1999). There are many watermelon cultivars that vary in shape, colour of the rind, and flesh, and some are seeded and other seedless. The shape of the fruit varies from globular to oblong, whereas the colour of the rind varies in shades of green from a pale yellowish green to a deep blackish-green. Watermelon has a thin, firm external rind, a layer of white-fleshed internal rind that varies in thickness, and an interior edible flesh.

Watermelon is rich in vitamin $\mathrm{C}$, vitamin $\mathrm{A}$, vitamin $\mathrm{B}$, amino acid and also carotenoid lycopene. The red flesh of watermelon contains some vitamin A (Anon, 2008). Watermelon is rich in vitamin $B$ that is primarily responsible for the production of energy in your body. Hence, consuming watermelon can boost your energy levels. Watermelon can be viewed as a more nutritious alternative to having energy drinks or supplements prior to exercise. Watermelons are also a good source of vitamin $\mathrm{C}$ with a cup $(8 \mathrm{oz})$ of watermelon juice containing $20 \%$ of the daily value for vitamin $\mathrm{C}$, which is an essential nutrient for humans because it aids in the synthesis of collagen in addition to protecting against oxidative damage. Vitamin $\mathrm{C}$ consumption has been shown to protect against stomach, oral, and lung cancers, improve cholesterol, and prevent scurvy (Fontham et al., 1988; Block, 1991; Ness et al., 1996).

Watermelons are an excellent source of lycopene and are a great option for consumers who want to consume lycopene but do not like the taste or texture of tomatoes and tomato products. Eight ounces of watermelon juice contains many nutrients and vitamins including: $10 \mathrm{mg}$ of lycopene and $19 \mathrm{mg}$ of vitamin $C$ in addition to beta-carotene, potassium, and vitamin A (USDA Nutrient Database, 2009). Lycopene and vitamin $\mathrm{C}$ are well-known antioxidants which provide many health benefits to humans. Lycopene in fresh watermelons is more bio available than in fresh tomatoes (Bliss, 2002).

Vitamin $\mathrm{C}$ is very sensitive to heat and degrades very quickly during pasteurization. PEF treatment may be a better option for vitamin $\mathrm{C}$ retention in fruit juices. Watermelon is rich in amino acid called citrulline, which helps us to produce another amino acid called arginine. According to the USDA Nutrient Database (2009), watermelons contain 40\% more lycopene (per $100 \mathrm{~g}$ ) than raw red ripe tomatoes. Lycopene is a carotenoid that provides the red color to tomatoes, watermelons, and red bell pepper, among other fruits 
and vegetables. Lycopene is a powerful antioxidant and has been shown to prevent various cancers and help against heart disease (Rao and Agarwal, 1999). Lycopene quenches free radicals which prevents oxidative damage which subsequently prevents many cancers. Fish et al. (2002) stated that watermelon is a gastronomically pleasing food and is rich in lycopene which makes it a highly desirable source of this phytochemical.

Watermelon juice is commonly consumed in Mexico and can be found in many American bars as a mixer for alcoholic beverages. Due to its low acidity and growing conditions, watermelon is regarded as a potentially hazardous food (FDA, 2001). In the fruit juice industry, juice is typically pasteurized by high temperature short time (HTST) pasteurization. This process uses plate heat exchangers to heat the sample quickly at least $78^{\circ} \mathrm{C}$. Although this method is effective at inactivating microorganisms and enzymes, it can cause detrimental effects on the quality of the juice. Heat treatment may cause color change, separation of particles, and a change in flavor and/or smell (Qin et al., 1995). If heat treatment is not performed rapidly or at a reasonably low temperature, the juice will begin to separate due to the destruction of pectin (Goodman et al., 2002). Compared with thermal pasteurization, non-thermal processing offers the advantages of low process temperatures which results in a better retention of flavors and nutrients (Vega-Mercado et al., 1997). Color and appearance are the first characteristic a consumer sees while shopping in a grocery store. Color may have an influence on a consumer's purchase intent. Fruit juices are generally packaged in clear plastic bottles with large labels so consumers can see the juice's color. Thermal pasteurization can cause pigments to degrade which may the color and appearance of fruit juice.

Generally, there is very little data or information related to changes of the properties of watermelon juice during storage time. Thus, the present study is to determine the chemical properties (vitamin-c and acidity), and sensorial characteristic changes of watermelon juice during storage at refrigeration temperature.

\section{Materials and Methods}

Fresh mature watermelon were purchased from local market in Sylhet with uniform in color and size and stored at $25^{\circ} \mathrm{C}$. The fruits were thoroughly washed with distilled water to remove dirt, dust, pesticide residues and then rinds were washed with pure ethanol to remove micro flora on the surface of the fruit prior to juice extraction. All glassware and knives were autoclaved at $121^{\circ} \mathrm{C}$ for $45 \mathrm{~min}$ and all other equipment was sanitized with hypochlorite prior to usage. The watermelons were cut into quarters and the flesh was scooped out and cut into small cubes. The cubes were placed in a laboratory scale juice processor. The extracted juice was then centrifuged and filtered. The filtered juice was placed in autoclaved screw-top glass bottles. The filtered watermelon juice, in screw-top glass bottles, was pasteurized in a covered water bath with high temperature short time $\left(72^{\circ} \mathrm{C}\right.$ for $15 \mathrm{~s}$ ) (Precision Water bath 180 Series, Chicago, IL). The treatments were made as pasteurized watermelon juice \{Treatment one, $\mathrm{T}_{1}$ (control)\}, pasteurized watermelon juice $+20 \%$ sucrose $\left(\mathrm{T}_{2}\right)$, pasteurized watermelon juice $+0.1 \%$ sodium benzoate $\left(\mathrm{C}_{6} \mathrm{H}_{5} \mathrm{COONa}\right)\left(\mathrm{T}_{3}\right)$, pasteurized watermelon juice $+20 \%$ sucrose $+0.1 \%$ sodium benzoate $\left(\mathrm{C}_{6} \mathrm{H}_{5} \mathrm{COONa}\right)\left(\mathrm{T}_{4}\right)$, pasteurized watermelon juice $+0.1 \%$ potassium sorbate $\left(\mathrm{CH}_{3}-\mathrm{CH}=\mathrm{CH}-\right.$ $\mathrm{CH}=\mathrm{CH}=\mathrm{COOK})\left(\mathrm{T}_{5}\right)$, pasteurized watermelon juice $+20 \%$ sucrose $+0.1 \%$ potassium sorbate $\left(\mathrm{CH}_{3}\right.$ $\mathrm{CH}=\mathrm{CH}-\mathrm{CH}=\mathrm{CH}=\mathrm{COOK}) \quad\left(\mathrm{T}_{6}\right), \quad$ pasteurized watermelon juice $+0.05 \%$ sodium benzoate $\left(\mathrm{C}_{6} \mathrm{H}_{5} \mathrm{COONa}\right)+0.05 \%$ Potassium Sorbate $\left(\mathrm{CH}_{3^{-}}\right.$ $\mathrm{CH}=\mathrm{CH}-\mathrm{CH}=\mathrm{CH}=\mathrm{COOK}) \quad\left(\mathrm{T}_{7}\right), \quad$ pasteurized watermelon juice $+20 \%$ sucrose $+0.05 \%$ sodium benzoate $\left(\mathrm{C}_{6} \mathrm{H}_{5} \mathrm{COONa}\right)+0.05 \%$ potassium sorbate $\left(\mathrm{CH}_{3}-\mathrm{CH}=\mathrm{CH}-\mathrm{CH}=\mathrm{CH}=\mathrm{COOK}\right) \quad\left(\mathrm{T}_{8}\right), \quad$ pasteurized watermelon juice $+0.1 \%$ sodium benzoate $\left(\mathrm{C}_{6} \mathrm{H}_{5} \mathrm{COONa}\right)+0.1 \%$ potassium sorbate $\left(\mathrm{CH}_{3^{-}}\right.$ $\mathrm{CH}=\mathrm{CH}-\mathrm{CH}=\mathrm{CH}=\mathrm{COOK}) \quad\left(\mathrm{T}_{9}\right), \quad$ pasteurized watermelon juice $+20 \%$ sucrose $+0.1 \%$ sodium benzoate $\left(\mathrm{C}_{6} \mathrm{H}_{5} \mathrm{COONa}\right)+0.1 \%$ potassium sorbate $\left(\mathrm{CH}_{3}-\mathrm{CH}=\mathrm{CH}-\mathrm{CH}=\mathrm{CH}=\mathrm{COOK}\right)\left(\mathrm{T}_{10}\right)$ and stored at refrigeration temperature $\left(4-15^{\circ} \mathrm{C}\right)$ for a period of three months.

\section{Chemical analysis}

Ascorbic acid was determined by the spectrophotometric method. The spectrophotometric method involves the oxidation of L-ascorbic acid to L-dehydroascorbic acid by bromine water in presence of acetic acid. L-dehydroascorbic acid, after coupling with the complexing agent, 2,4dinitrophenylhydrazine at $37^{\circ} \mathrm{C}$ temperature for three hours form osazone. The osazone of dehydroascorbic acid is treated with $85 \% \mathrm{H}_{2} \mathrm{SO}_{4}$ to produce a red color compound whose absorbance is measured soectrophotometrically at $\lambda_{\max }=521 \mathrm{~nm}$ by UV/VIS spectrophotometer. Acidity was determined by dissolving a known weight of sample in distilled water and titration against $0.1 \mathrm{~N} \mathrm{NaOH}$ using phenolphthalein as indicator (Srivastava and Sanjeev, 2003). 


\section{Sensory analysis}

A panel of ten judges selected from staff and students of food engineering and tea technology department evaluate the product fortnightly for color, flavor, and overall acceptability by the method of Larmond ( 1977) using a scale from 1 to 9 , where 1 presented extremely disliked and 9 represent extremely liked.

\section{Statistical analysis}

The data obtained was subjected to statistical analysis using RCBD (Randomized Complete Block Design) and the means were compared by using LSD (Least Significance Difference) test (Steel and Torrie, 1980). For all the analyses, the alpha error was set at $0.05 \%$.

\section{Results and Discussion}

Results showed that storage period and temperature had significant effect on ascorbic acid content of different samples. There was a gradual decrease in ascorbic acid of watermelon juice from $2.360 \mathrm{mg}$ initially to $1.498 \mathrm{mg}$. Results show that minimum percentage decrease in ascorbic acid content was recorded in sample $\mathrm{T}_{10}(23.85 \%)$ and maximum $\mathrm{T}_{1}$ $(51.85 \%)$ (Table: 1) and percentage of decrease of ascorbic acid for each treatment shown graphically (Figure: 1). Ascorbic acid is the most difficult vitamin to be preserved during pasteurization. As it is the least stable vitamin, it decreases in the product during storage.
Acidity of samples $\left(\mathrm{T}_{1}\right.$ to $\left.\mathrm{T}_{10}\right)$ ranged from 0.09 to 0.13 , which were gradually increased to 0.123 to 0.201 during three months of storage. The mean values increased from 0.106 to 0.188 . Maximum mean values were recorded in sample $T_{1}(0.201)$ followed by $T_{2}(0.181)$, while minimum mean values were observed in sample $T_{5}(0.123)$ followed by $T_{9}$ (0.129). During storage maximum increase was observed in sample $\mathrm{T}_{1}(107.69 \%)$ followed by $\mathrm{T}_{2}$ and $\mathrm{T}_{3}(100.00 \%)$, while minimum increase was observed in $\mathrm{T}_{10}(50.00 \%)$ followed by $\mathrm{T}_{6}(54.54 \%)$ (Table: 2$)$ and percentage of increase of acidity for each treatment shown graphically (Figure: 2 ). The information of this study indicates that storage intervals and treatments had a significant effect on acid content of juice during storage due to break down of pectin to pectenic acid (Riaz et al). The analysis of our data showed that storage period and treatments had a significant on overall acceptability (obtained from color, flavor and odor) of the watermelon juice. The mean score of judges decrease from 6.943 to 2.540. Maximum mean score of judges was recorded in $\mathrm{T}_{10}$ (5.727) followed by $\mathrm{T}_{8}$ (5.463), while minimum mean score of judges was recorded in $\mathrm{T}_{1}$ (3.919) followed by $\mathrm{T}_{2}$ (4.204). Maximum decrease was observed in sample $\mathrm{T}_{2}(86.52 \%)$ followed by $\mathrm{T}_{1}(85.29 \%)$, while minimum decrease was observed in $\mathrm{T}_{8}(43.82 \%)$ followed by $\mathrm{T}_{6}$ (47.54\%), (Table: 3 ) and percentage of decrease of overall acceptability for each treatment shown graphically (Figure: 3). The findings of this study showed that the product preserved with chemical preservatives retain maximum overall acceptability during storage.

Table 1. Effect of treatments and storage on ascorbic acid $(\mathrm{mg} / 100 \mathrm{ml})$ of watermelon juice

\begin{tabular}{|c|c|c|c|c|c|c|c|c|c|}
\hline \multirow[t]{2}{*}{ Treatments } & \multicolumn{7}{|c|}{ Intervals ( days) } & \multirow[t]{2}{*}{ Means } & \multirow{2}{*}{$\begin{array}{l}\% \text { of } \\
\text { decrease }\end{array}$} \\
\hline & $1^{\mathrm{st}}$ & $15^{\text {th }}$ & $30^{\text {th }}$ & $45^{\text {th }}$ & $60^{\text {th }}$ & $75^{\text {th }}$ & $90^{\text {th }}$ & & \\
\hline $\mathrm{T}_{1}$ & $2.70 \pm 0.04$ & 2.10 & 1.80 & 1.60 & 1.40 & 1.30 & 1.30 & $1.743 \pm 0.51^{\mathrm{ab}}$ & 51.85 \\
\hline$\overline{\mathrm{T}_{2}}$ & 1.80 & 1.65 & 1.40 & 1.40 & 1.30 & 1.25 & 1.20 & $1.429 \pm 0.22^{\mathrm{a}}$ & 33.33 \\
\hline$\overline{T_{3}}$ & 2.10 & 1.90 & 1.70 & 1.65 & 1.60 & 1.50 & 1.50 & $1.707 \pm 0.22^{\mathrm{ab}}$ & 28.57 \\
\hline $\mathrm{T}_{4}$ & 2.70 & 2.30 & 1.90 & 1.70 & 1.63 & 1.55 & 1.50 & $1.897 \pm 0.45^{\mathrm{ab}}$ & 44.44 \\
\hline $\mathrm{T}_{5}$ & 2.30 & 2.00 & 1.85 & 1.70 & 1.60 & 1.50 & 1.50 & $1.779 \pm 0.29^{\mathrm{ab}}$ & 34.78 \\
\hline $\mathrm{T}_{6}$ & 2.80 & 2.60 & 2.40 & 2.20 & 2.00 & 1.80 & 1.70 & $2.214 \pm 0.41^{b}$ & 39.28 \\
\hline $\mathrm{T}_{7}$ & 2.10 & 2.00 & 2.80 & 2.80 & 1.70 & 1.60 & 1.50 & $2.017 \pm 0.54^{\mathrm{ab}}$ & 28.57 \\
\hline $\mathrm{T}_{8}$ & 2.70 & 2.45 & 2.10 & 2.00 & 1.80 & 1.70 & 1.65 & $2.057 \pm 0.39^{\mathrm{ab}}$ & 38.89 \\
\hline $\mathrm{T}_{9}$ & 1.80 & 1.70 & 1.65 & 1.65 & 1.50 & 1.35 & 1.15 & $1.543 \pm 0.23^{\mathrm{a}}$ & 36.11 \\
\hline $\mathrm{T}_{10}$ & 2.60 & 2.41 & 2.29 & 2.19 & 2.09 & 2.00 & 1.98 & $2.223 \pm 0.23^{\mathrm{b}}$ & 23.85 \\
\hline Means & $\begin{array}{l}2.360 \\
\pm 0.39^{\mathrm{d}}\end{array}$ & $\begin{array}{l}2.111 \\
\pm 0.32^{\mathrm{c}} \\
\mathrm{d}\end{array}$ & $\begin{array}{l}1.989 \\
\pm 0.41^{\mathrm{b}} \\
\mathrm{cd}\end{array}$ & $\begin{array}{l}1.889 \\
\pm 0.41^{\text {abc }}\end{array}$ & $\begin{array}{l}1.66 \\
2 \\
\pm 0.2 \\
5^{\text {abc }}\end{array}$ & $\begin{array}{l}1.555 \\
\pm 0.23^{\mathrm{a}} \\
\mathrm{b}\end{array}$ & $\begin{array}{l}1.498 \pm 0 \\
.25^{\mathrm{a}}\end{array}$ & & \\
\hline
\end{tabular}

Note: Values followed by different letters are significantly $(\mathrm{p}<0.05)$ different from each other 
Table 2. Effect of treatments and storage on acidity (\%) of watermelon juice

\begin{tabular}{|c|c|c|c|c|c|c|c|c|c|}
\hline \multirow[t]{2}{*}{ Treatments } & \multicolumn{7}{|c|}{ Intervals ( days) } & \multirow[t]{2}{*}{ Means } & \multirow{2}{*}{$\begin{array}{l}\% \text { of } \\
\text { increase }\end{array}$} \\
\hline & $1^{\text {st }}$ & $15^{\text {th }}$ & $30^{\text {th }}$ & $45^{\text {th }}$ & $60^{\text {th }}$ & $75^{\text {th }}$ & $90^{\text {th }}$ & & \\
\hline $\mathrm{T}_{1}$ & 0.13 & 0.15 & 0.18 & 0.22 & 0.22 & 0.24 & 0.27 & $0.201 \pm 0.05^{\mathrm{c}}$ & 107.69 \\
\hline $\mathrm{T}_{2}$ & 0.12 & 0.14 & 0.14 & 0.18 & 0.21 & 0.24 & 0.24 & $0.181 \pm 0.05^{\mathrm{bc}}$ & 100.00 \\
\hline $\mathrm{T}_{3}$ & 0.09 & 0.11 & 0.13 & 0.15 & 0.17 & 0.17 & 0.18 & $0.143 \pm 0.03^{\mathrm{ab}}$ & 100.00 \\
\hline $\mathrm{T}_{4}$ & 0.12 & 0.13 & 0.13 & 0.15 & 0.15 & 0.17 & 0.19 & $0.149 \pm 0.02^{\mathrm{abc}}$ & 58.33 \\
\hline $\mathrm{T}_{5}$ & 0.09 & 0.10 & 0.12 & 0.12 & 0.13 & 0.14 & 0.16 & $0.123 \pm 0.02^{\mathrm{a}}$ & 77.78 \\
\hline $\mathrm{T}_{6}$ & 0.11 & 0.12 & 0.12 & 0.13 & 0.15 & 0.15 & 0.17 & $0.136 \pm 0.02^{\mathrm{ab}}$ & 54.54 \\
\hline $\mathrm{T}_{7}$ & 0.09 & 0.11 & 0.13 & 0.15 & 0.15 & 0.16 & 0.16 & $0.136 \pm 0.03^{\mathrm{ab}}$ & 77.78 \\
\hline $\mathrm{T}_{8}$ & 0.10 & 0.12 & 0.12 & 0.14 & 0.15 & 0.17 & 0.17 & $0.139 \pm 0.03^{\mathrm{ab}}$ & 70.00 \\
\hline $\mathrm{T}_{9}$ & 0.09 & 0.11 & 0.11 & 0.13 & 0.14 & 0.16 & 0.16 & $0.129 \pm 0.03^{\mathrm{ab}}$ & 77.78 \\
\hline $\mathrm{T}_{10}$ & 0.12 & 0.12 & 0.13 & 0.13 & 0.15 & 0.15 & 0.18 & $0.140 \pm 0.02^{\mathrm{ab}}$ & 50.00 \\
\hline Means & $\begin{array}{l}0.106 \\
\pm 0.01^{\mathrm{a}}\end{array}$ & $\begin{array}{l}0.121 \\
\pm 0.01^{\text {bc }}\end{array}$ & $\begin{array}{l}0.131 \\
\pm 0.02^{\mathrm{abc}}\end{array}$ & $\begin{array}{l}0.150 \\
\pm 0.03^{\text {bcd }}\end{array}$ & $\begin{array}{l}0.162 \\
\pm 0.03^{\mathrm{c}}\end{array}$ & $\begin{array}{l}0.175 \\
\pm 0.03^{\text {de }}\end{array}$ & $\begin{array}{l}0.188 \\
\pm 0.04^{\mathrm{e}}\end{array}$ & & \\
\hline
\end{tabular}

Note: Values followed by different letters are significantly $(\mathrm{p}<0.05)$ different from each other

Table 3. Effect of treatments and storage on overall acceptability of watermelon juice

\begin{tabular}{|c|c|c|c|c|c|c|c|c|c|}
\hline \multirow[t]{2}{*}{ Treatments } & \multicolumn{7}{|c|}{ Intervals ( days) } & \multirow[t]{2}{*}{ Means } & \multirow{2}{*}{$\begin{array}{l}\% \text { of } \\
\text { decrease }\end{array}$} \\
\hline & $1^{\text {st }}$ & $15^{\text {th }}$ & $30^{\text {th }}$ & $45^{\text {th }}$ & $60^{\text {th }}$ & $75^{\text {th }}$ & $90^{\text {th }}$ & & \\
\hline $\mathrm{T}_{1}$ & 6.80 & 5.10 & 5.10 & 4.30 & 3.68 & 1.45 & 1.00 & $3.919 \pm 2.08^{\mathrm{a}}$ & 85.29 \\
\hline $\mathrm{T}_{2}$ & 7.42 & 6.20 & 5.24 & 4.12 & 3.00 & 2.45 & 1.00 & $4.204 \pm 2.24^{\mathrm{a}}$ & 86.52 \\
\hline $\mathrm{T}_{3}$ & 6.68 & 5.32 & 5.10 & 5.00 & 4.48 & 2.63 & 2.00 & $4.459 \pm 1.62^{\mathrm{a}}$ & 70.06 \\
\hline $\mathrm{T}_{4}$ & 7.10 & 6.45 & 6.00 & 5.65 & 5.00 & 3.32 & 2.10 & $5.089 \pm 1.78^{\mathrm{a}}$ & 70.42 \\
\hline $\mathrm{T}_{5}$ & 6.75 & 5.45 & 5.20 & 5.00 & 3.88 & 2.55 & 2.62 & $4.493 \pm 1.55^{\mathrm{a}}$ & 61.18 \\
\hline $\mathrm{T}_{6}$ & 6.90 & 5.80 & 5.60 & 5.65 & 5.00 & 3.45 & 3.62 & $5.146 \pm 1.24^{\mathrm{a}}$ & 47.54 \\
\hline $\mathrm{T}_{7}$ & 6.66 & 5.45 & 4.90 & 5.45 & 5.00 & 2.50 & 2.50 & $4.637 \pm 1.57^{\mathrm{a}}$ & 62.46 \\
\hline $\mathrm{T}_{8}$ & 7.12 & 6.00 & 5.80 & 6.00 & 5.42 & 3.90 & 4.00 & $5.463 \pm 1.16^{\mathrm{a}}$ & 43.82 \\
\hline $\mathrm{T}_{9}$ & 6.55 & 5.45 & 4.88 & 4.88 & 4.43 & 2.87 & 2.68 & $4.534 \pm 1.37^{\mathrm{a}}$ & 59.08 \\
\hline $\mathrm{T}_{10}$ & 7.45 & 6.34 & 6.12 & 6.32 & 5.66 & 4.32 & 3.88 & $5.727 \pm 1.24^{\mathrm{a}}$ & 47.92 \\
\hline Means & $\begin{array}{l}6.943 \\
\pm 0.32^{\mathrm{d}}\end{array}$ & $\begin{array}{l}5.756 \\
\pm 0.47^{\mathrm{c}}\end{array}$ & $\begin{array}{l}5.394 \\
\pm 0.45^{\mathrm{bc}}\end{array}$ & $\begin{array}{l}5.237 \\
\pm 0.71^{\text {bc }}\end{array}$ & $\begin{array}{l}4.555 \\
\pm 0.83^{\mathrm{b}}\end{array}$ & $\begin{array}{l}2.944 \\
\pm 0.82^{\mathrm{a}}\end{array}$ & $\begin{array}{l}2.540 \\
\pm 1.07^{\mathrm{a}}\end{array}$ & & \\
\hline
\end{tabular}

Note: Values followed by different letters are significantly $(\mathrm{p}<0.05)$ different from each other

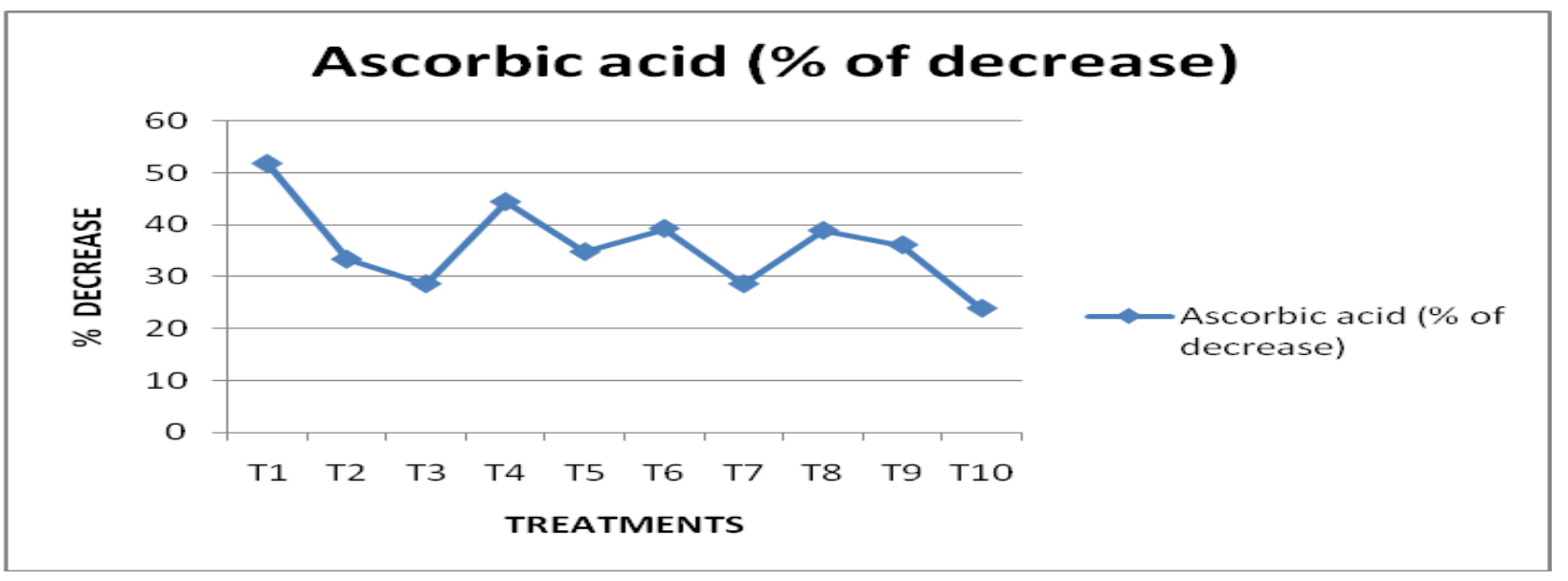

Fig. 1: Percentage of decrease of ascorbic acid in each treatment after ninety days 


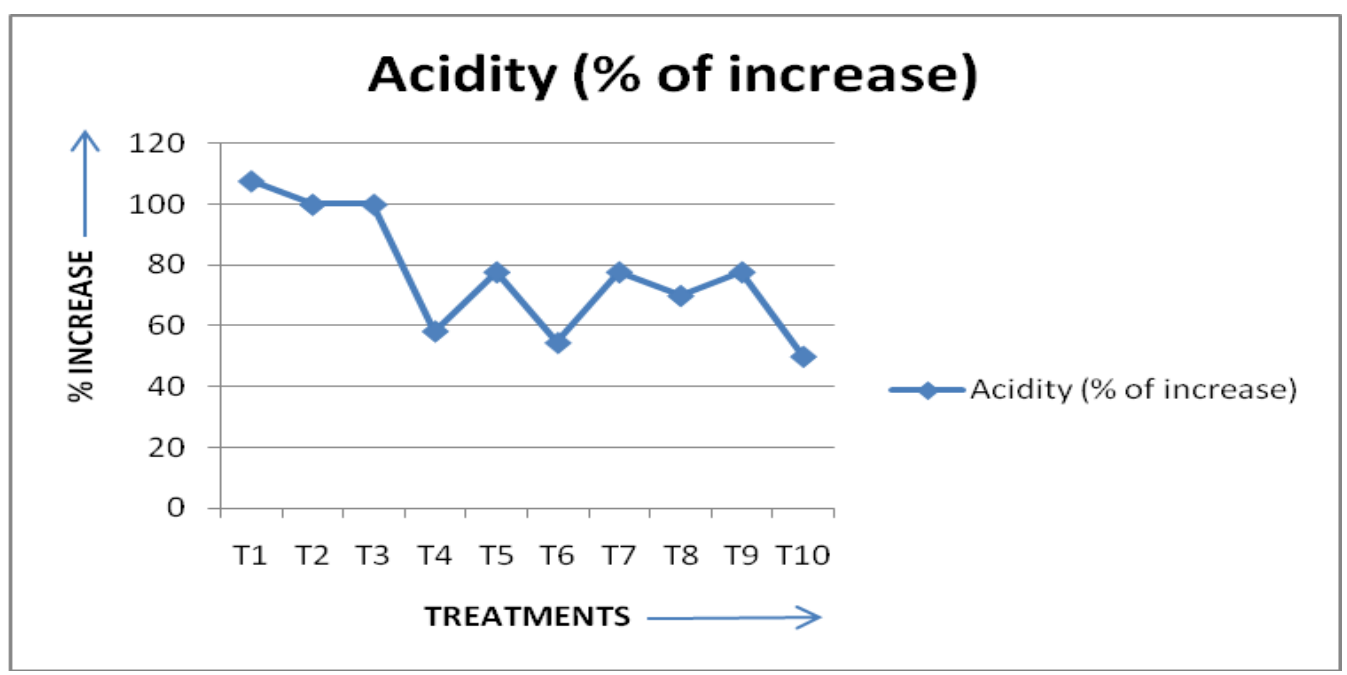

Fig. 2: Percentage of increase of acidity in each treatment after ninety days

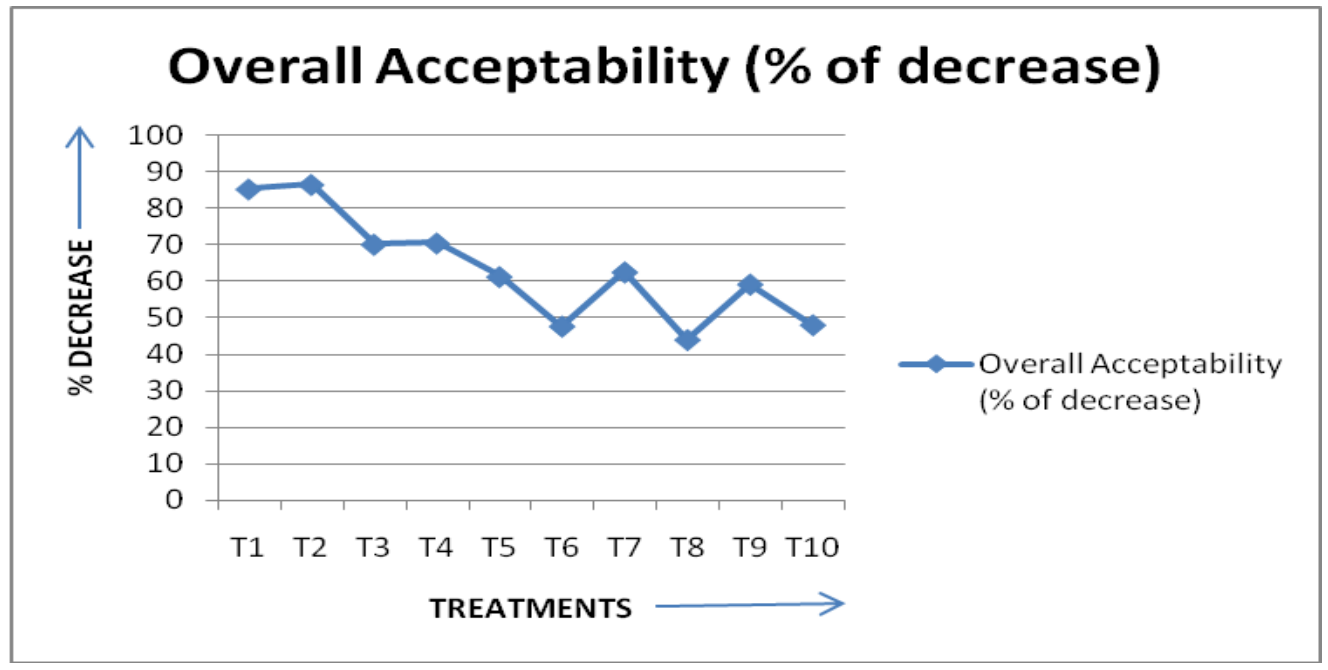

Fig. 3: Percentage of decrease of overall acceptability in each treatment after ninety days

\section{Conclusion}

Finally from the study it can be concluded pasteurized juice with $20 \%$ sucrose, 0.05 or $0.1 \%$ sodium benzoate and 0.05 or $0.1 \%$ potassium sorbate were found most acceptable sensory evaluation and retention of most of the nutrients during 3 months storage.

\section{References}

Anon. 2008. Watermelon. Booklet of Federal Agriculture Marketing Authority (FAMA), Utusan Printcorp Sdn Bhd.

Avgi, S. 1969. Melons. Ministry of Agriculture and Natural Resources, Cyprus. pp 207-210.

Bliss, R. 2002. Watermelon shows its lycopene stripes.USDA.

http://www.ars.usda.gov/is/pr/2002/020604. htm. Accessed on June 4, 2009. 
Block, G. 1991. Vitamin C and cancer prevention: the epidemiologic evidence. American Journal of Clinical Nutrition, 53: 270-282.

Fish, W.; Perkins-Veazie P. and Collins. J. 2002. A quantitative assay for lycopene that utilizes reduced volumes of organic solvents. Journal of food composition and analysis, 15(3): 309-317.

Fontham, E.; Pickle, L.; Haenszel,W.; Correa, P.; Lin, $\mathrm{Y}$ and Falk, R. 1988. Dietary Vitamins A and $\mathrm{C}$ and Lung Cancer Risk in Louisiana. Cancer, 62(10): 2267-2273.

Food and Drug Administration (FDA). 2001. Evaluation and definition of potentially hazardous foods. http://vm.cfsan.fda.gov/ comm/ift4-3.html. Accessed on March 24, 2009.

Goodman, C.; Fawcett, S. and S. Barringer, S. 2002. Flavor, viscosity and color analyses of hot and cold break tomato juices. Journal of Food Science, 67(1): 404-408.

Larmond, L. E. 1977. Method for sensory evaluation of food. Canada Dept. of Agriculture, Publ., 1286: $36-37$

Ness, A.; K. Khaw, T.; Bingham, S. and Day, N. E. 1996. Vitamin C status and serum lipids. European Journal of Clinical Nutrition, 50(11): 724-729.

Qin, B.; Pothakamury, L.; Vega, H.; Martin, O.; Barbosa-Ganovas, G. and Swanson. B.1995. Food Pasteurization using high-intensity pulsed electric fields. Food Technology, 49(12): 55-60.

Rao, A. V. and Agarwal, S. 1999. Role of Lycopene as Antioxidant Carotenoid in the Prevention of Chronic Diseases: A Review Nutrition Research, 19(2): 305-323.
Riaz, R. A.; Ali A, and Saleem, M. 1988. Studies on the preparation and storage stability of comminuted kinow fruit beverage bees. Pak. J. Sci. Ind. Res., 32(8): 574-578.

Snowdon, A. L. 1990. In Color Atlas of Postharvest: Quality of Fruit and Vegetable, (Nunes, Maria Cecilia do Nascimento eds.), pp.207209, Blackwell Publishing.

Srivastava, R. P. and Sanjeev, K. 2003. Fruit and vegetable preservation principles and practices: Important methods for analysis of Fruits? Vegetables and their products. Third Revised and Enlarge Edition. International Book Distribution Co., Lucknow, India :363.

Steel, R. G. D. and Torrie, J. H. 1980. Principle and procedures of statistics. Mc Graw Hill Book Co. NY, U.S.A, 2nd ed, pp: 195-238.

United States Department of Agriculture (USDA) Nutrient Lab. Watermelon. http://www.ars.usda.gov/main/site_main.htm ?modecode=12-35-45-00. Accessed March 24, 2009.

Vega-Mercado, H.; Martín-Belloso, O.; Qin, B.; Chang, F.; Góngora-Nieto, M.; BarbosaCánovas, G. and Swanson, B. 1997. Nonthermal food preservation: Pulsed electric fields. Trends in Food Science and Technology, 8(5): 151-157.

William, C. H. 1999. The University of Georgia College of Agricultural and Environmental Sciences Cooperative Extension Service. http://pubs.caes.uga.edu/caespubs/pubcd/B9 96-w.html. (Retrieved on 23/3/2009). 